\title{
Political Aspect of the Saving - Investment Gap in Croatia
}

\author{
Damir Piplica ${ }^{1, *}$ \\ ${ }^{1}$ University Department of Professional Studies Split, 21000 Split, Kopilica 5, Croatia \\ *Correspondence: University Department of Professional Studies Split, 21000 Split, \\ Kopilica 5, Croatia. E-mail: damir.piplica@gmail.com
}

Received: October 13, 2015 Accepted: November 12, 2015 Published: December 7, 2015

doi:10.5296/rae.v7i4.8420 URL: http://dx.doi.org/10.5296/rae.v7i4.8420

\begin{abstract}
All the Governments of Croatia should acknowledge the importance of the economic policy that will encourage higher saving rates thus enabling correlation with the investment rate with the scope of reaching important macroeconomic goals, such as the GDP and employment rates increase, etc., without in any way endangering the macroeconomic stability of the national economy. Regardless of the great impact savings had on the investments, the implementation of the economic or investment policy on behalf of the Right-wing Government of Croatia had a great impact in creating the discrepancy in the saving-investment ratio, than it was the case with the Left-wing Government of Croatia. If the Right-wing Government of Croatia starts implementing the economic policy with the sole scope of reaching higher saving rates than the former ones, complying with their ideology, and focusing less on how to opportunistically reach middle voters, they will influence effectively the saving and investment correlation, thus lessening the saving-investment gap and reaching the macroeconomic stability. However, if the Right-wing Government opportunistically turn to the "middle voters" instead of following their ideology`s programme, this could lead to the decrease in efficiency of some economic policy measures with the goal of reaching a certain saving-investment correlation. On the other hand, with the growth in saving rates, Left-wing Government of Croatia can influence effectively its correlation with the investment rates, but still in a lesser proportion compared to the Right-wing Government of Croatia. With the Left-wing Government of Croatia opportunistically orienting on the "middle voters" that would facilitate their position in achieving the macroeconomic stability and thus enforcing their influence on the saving-investment correlation, as would not be the case if only complying with their left oriented party`s programme.
\end{abstract}

Keywords: saving, investment, political parties, economic policy, transition economy 


\section{Introduction}

Croatia has introduced a number of reforms from the moment it obtained its Independence, with more or less success, with the sole scope of bringing its economy closer to the modern market conditions of making money. The new found transition environment alongside other atrocities caused in the war in Croatia, resulted in particularities as were not present in the developed economy markets, which called for a different approach in dealing with the already existing economic problems. On the other hand that unique succession of historical events enabled the research of some of the economic phenomena that could act differently in regards to conditions existing in the developed economy markets. Even though the transition process in Croatia is coming to an end, with Croatia as a full time European Union member, its economic growth is still under the European Union average. Therefore it is vital for a special care being given to the investment and saving rates correlation, that would directly or indirectly impact the reaching of other macroeconomic goals such as the growth in GDP, in employment rates, in citizens` living standards, etc.

However, lack in possessing own means, and more often than not lack of patience in reaching sought after goals with poor comprehension and knowledge of economic lawfulness and similar, can have a major influence on political power 'elites in offsetting certain investment activities significantly surpassing their real capacities. This can result in a long term macroeconomic instability of the Croatian economy with numerous negative effects. Therefore the creating of the saving-investment gap in Croatia in its specific transition economy has been the core of the research conducted. Taking into consideration the importance the political goals of both Right - wing and Left - wing Governments can have as a main factor in creating the saving-investment gap, additional ponder in this research are the circumstances themselves, that arise when either one or the other orientation in Croatia is in governance.

Results obtained from the research have a starting point in Keynes`s saving-investment ratio considerations on the economy markets. The results obtained will be considered in regard to already existing ideological and opportunistic models explaining implementation of the Left or Right- wing Governments` economic policies. The conclusions obtained from the research can serve as practical guidelines to the Governments of Croatia stating that in the process of implementing the economic policy they should pay attention to the consequences arising from their own economic policy in creating the saving- investment gap. If these consequences are being neglected from both parties, regardless of their orientation, this can lead the Governments of Croatia failing in reaching sought after economic goals.

\section{Theoretical Concept and Empiric Research}

All savings in their substance consist in the voluntary preserving of material goods or money from useless spending at the present moment or the delay in its spending for some time to come, with the scope of enabling greater consumption later in time. On the other hand, investments gaining growth in disposable equity of certain national economy increase the 
product capacity, allowing greater consumption of material goods in the future.

The support for this thinking can be found in Keynesian (1936) theoretical concept that lies in the assumption that savings stand for the difference between the income and consumption performed in a certain period of a time. Therefore the investments stand for certain expenses coming from other benefits, not from the consumables` expense. Keynes strongly believes that the saving-investment balance is an important condition in macroeconomic stability alongside other conditions. It was the saving- investment ratio that became the focus of interest for many authors, publishing their findings in different conditions, and from different assumptions. It did not come as a surprise the notion that in the research conducted, some very contradictory results emerged eventually.

Authors like Ramsey (1928), Solow (1956), Cass (1965), Koopmans (1965) in their non classical growth models in closed economies, established the correlation between the domestic saving and economic growth. When speaking of open economies, nowadays all countries in the world have the latter, there wouldn't be a correlation between the two, since the foreign saving could easily take over the role of the domestic saving. Feldstein and Horioka (1980) came to the same conclusion proving there is a positive correlation between domestic saving and investment, if there is no perfect replacement of the domestic with foreign saving. In times of the perfect capital mobility in the world, there is a weak correlation, if any, between domestic investments and savings. Feldstein (1983) calculated that for 17 OECD countries for the period from the 1974 till the 1979 each extra dollar of domestic saving increases domestic investment by approximately 85 cents.

Obstfeld (1986) points out slow change in demographic and technological factors that have an impact on saving and investment going in the same direction. Frankel (1992) proved that even in terms of ideal capital mobility, savings ' mobility has an impact on the real interest rate, with investments moving along the same way as savings. Obstfeld and Rogoff (1997) concluded that the interest rate on the global level will affect the connection in the saving investment ratio and their equalizing. Schneider (1999) conducted an interesting research, stating that developing countries had a weaker saving -investment correlation than was the case in developed countries. Blanchard and Giavazzi (2002) noticed the saving - investment gap, realizing that less developed countries in the EU save less and invest more, unlike developed countries inside the EU. Cooray and Sinha (2007) investigated into the saving -investment ratio in the areas of Sub-Saharan African countries without noticing any correlation between the two. De Wet and Eyden (2005) realised that foreign aid and foreign direct investment have an impact on the size of investments in Sub-Saharan African countries. Afzal (2007) studied the saving-investment correlation in developing countries, noticing the two ways cause-consequence saving investment correlation in South Africa, also realising how investment affects the investments in Pakistan and Sri Lanka, without reversibly altering impacts of investments on savings. He also noticed the lack in mutual saving - investment correlation in India, Philippines, Malaysia and Iran.

Aizenman et al. (2007) calculate cumulative saving-investment gaps for the period of 1993-2010 stating that countries with low or medium equity levels, but with lesser portion of 
foreign investment in domestic capital financing will eventually have greater economic growth than countries with higher portion of foreign saving. Prasad et al. (2007) concluded that less developed countries reach higher economic growth if leaning less on foreign investment sources. Esso and Keho (2010) conducted their research on eight West African countries (Benin, Burkina Faso, Cote d'Ivoire, Guinea Bissau, Mali, Niger, Senegal and Togo), and they came up with a number of variable data in regards to the saving-investment correlation. Mishra, et al. (2010) noticed that the saving - investment correlation is being affected by the capital mobility, current account targeting, etc.

Sanjib and Joice (2011), on the other hand, investigated into the saving - investment ratio in the USA, UK, China and India noticing their mutual correlation. Onafowara et al. (2011), proved significant saving - investment correlation, taking as an example six West European developed countries. Bahmani-Oskooee et al., (2012) unlike some formerly stated authors, noticed that countries lacking in domestic saving for investment financing, need to seek out the foreign resources abroad, or otherwise they are risking the lesser economic growth. Adom and Elbahnasawy (2014) realised that in developing countries there is a low saving rate and great saving - investment gap, thus enabling the economic growth.

\section{Applied Model and Research Methods}

In this research we are starting from the basic assumption that the saving - investment balance, known as the $\mathrm{S}=\mathrm{I}$, is the prerequisite for the macroeconomic balance of a given economy, that should be viewed as a dynamic process in a longer period of time. Croatian economy proves to be rather open with significant share in the international exchange in relation to the GDP. However, our presumption is that only saving-investment balance ensures Croatian economy stability whereas their discrepancy will stand for a certain form of the macroeconomic destabilization.

We are of the opinion that all the activities conducted by the former Governments of Croatia were in a great deal influenced by the political power of the parties in governance at the moment. The research conducted investigates into the parties' behaviour that can significantly differ depending on their Left or Right Wing beliefs, and thus can affect their economic policy implementation. Moreover, in this research the total investment and gross national savings will be included categories, for each year depending whether the Right or Left - wing parties were in the governance at the time (party's coalition). In the light of these findings, our assumption is that parties in economic policy implementation can stay true to their ideological omen or they can turn to the so called ,middle voters“.

We considered certain findings obtained from Nordhaus`s research (1975) who believed that every politician, regardless of his own beliefs and ideologies, wants to be in governance, which implies their opportunistic behaviour. Since voters remember vividly only the sequence of events that took place recently, parties in governance benefit from the so called „short - term memory“, and are trying to create the idea of prosperity while using their expansive policy right before elections. The consequences from that policy will emerge once 
the restrictive policy starts being conducted. Nordhaus`s assumptions served as a starting point for a number of research, with certain rational expectations being integrated. However, in this research the aforementioned notions will not be further analysed.

Hibbs`s findings (1977) will be considered in this research. He took a stand that politicians follow their ideologies when trying to win elections so they can eventually reach certain economic goals that will be of a benefit to those layers of society that elected them. He simply concluded that the Left - wing parties are more interested in reaching the higher employment rates and economic growth than in inflation decrease, which is not the case with the Right - wing parties. Depending on how the elections go, the economic policy implied will be one of the aforementioned. His assumptions proved essential for other research as well, with the rational expectations being introduced once again.

Our main hypothesis parts from the fact that in times this research was conducted in Croatia, there was a significant distinction between total investments and gross national savings. With lower GDP levels than most other EU countries, Croatia cannot dispose of the savings level that will insure necessary sources for the investment financing, which can lead to politicians in government trying to increase the economic growth far beyond their means, with the negative consequences reflected on Croatian economy. Another phenomena investigated will be the further analysis into the ways ideologies of either Left or Right - wing Governments in Croatia, affect the saving - investment gap and macroeconomic stability of the country, for the sole purpose of their reaching certain macroeconomic goals.

The data obtained was statistically analyzed from the findings emerged from the applied model for the period from 1992-2014. Croatia underwent several election cycles after the democratic changes it suffered. This in our opinion sets ground for the results obtained from the research.

\section{Data, Estimation and Results}

\subsection{Croatia and EU Countries}

Analyzing data for the period observed, consisting in saving - investment rates in Croatia compared to those of other EU countries, some dissimilarities will inevitably emerge. If we analyse first the average saving rates in Croatia for each and every year from the 1992-2014, we can see it varied from $4.89 \%$ to $23.49 \%$. Rather lower saving rates were registered in the far 1992, 1993 and 1995, years in which Croatia suffered terrible losses in the Homeland War, when the defence of the country from its enemy was the sole, higher priority.

The average saving rate in Croatia in 2002 was not higher than $20 \%$, except in 1994, and only in the period from 2003-2008 was above the former level. On the other hand, the average saving rate annually, for present EU counties was around $20-22 \%$. As is clear from the graphic ration in graph no.1, analysis of saving rates in Croatia compared to those of EU counties for the period of the 1992-2014, shows that they were much higher in the EU countries and in continuity than in Croatia. It was only in the period from the 2003-2009, that 
Croatia marked higher saving rates compared to other EU countries, which was an important factor in trying of Croatia to decrease its progress in development compared to what was the EU average estimate.

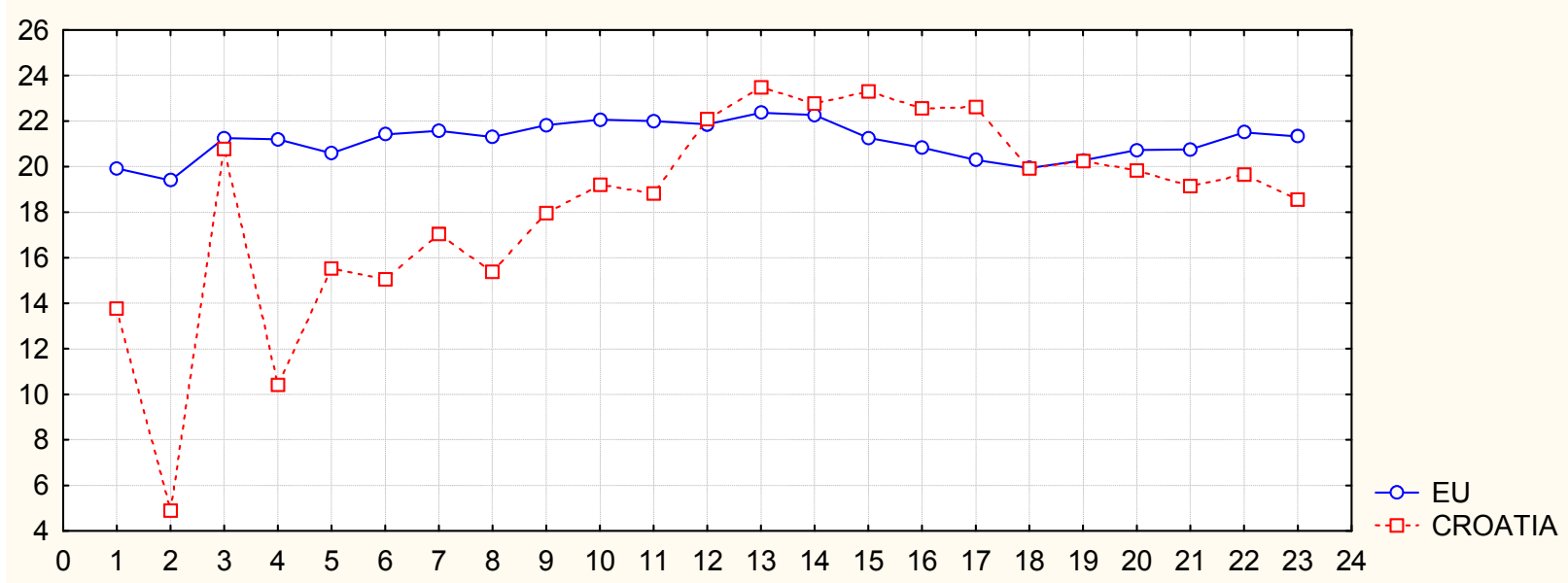

Graph 1. Saving Rate in EU (Present Countries) and Croatia 1992-2014

Source: IMF, WEO Database April 2015, Own Calculation

Regardless of the fact that saving rate in that period was beyond average compared to that in other EU countries, investment rate, on the other hand, was higher than was the EU average rate. It was around $22.22 \%$ (even if you take into consideration that it reached only $0.6 \%$ in 1993), whilst average rate of the present EU countries for that period of time was $21.12 \%$, as is evident from the graph no.2. However, average investment rate in Croatia was instable and it varied in relation to EU and it reached $17.87 \%$ to $31.43 \%$ (years of the War not being analyzed), while the saving rate of the present EU countries proved solid and it was $19.4 \%$ to 22.26\%. Adopting that policy in Croatia was not possible without creating a saving-investment gap with the additional consequences on the macroeconomic stability.

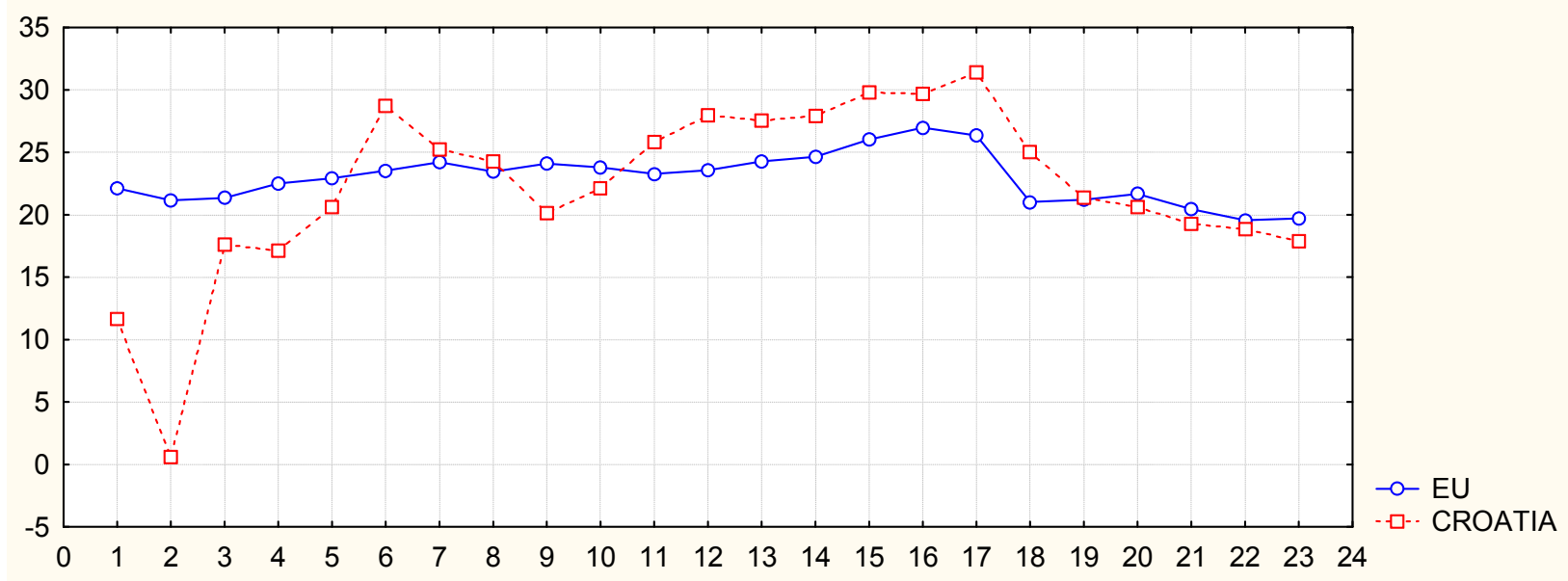

Graph 2. Investment Rate in EU (Present Countries) and Croatia 1992-2014

Source: IMF, WEO Database April 2015, Own Calculation 


\section{Macrothink}

Our null hypothesis can be tested once we acknowledge that saving and investment at hand are two sides of one medal. Data for savings and investments are in the table no. 2. The dependant t-test is testing our null hypothesis that there are no differences between the data of the two connected groups $\left(\mathrm{H}_{0}: \mu_{1}=\mu_{2}\right)$. In this context we will test our hypothesis proving there is no distinction between the two.

$$
t=\frac{\overline{x_{1}}-\overline{x_{2}}}{\sqrt{\frac{S_{1}^{2}}{n_{1}}+\frac{S_{2}^{2}}{n_{2}}}}
$$

Table 1. Investment and Saving in Croatia 1992-2014 (Left-wing Government was in governance in the period from the 2000-2003, and in the 2012-2014)

\begin{tabular}{|c|c|c|c|c|c|c|c|c|c|c|}
\hline Years & $\begin{array}{c}\text { Total } \\
\text { investment } \\
\% \text { GDP }\end{array}$ & $\begin{array}{c}\text { Gross } \\
\text { national } \\
\text { saving } \\
\% \text { GDP }\end{array}$ & $\begin{array}{l}\text { Predicted } \\
\text { value }\end{array}$ & Residual & $\begin{array}{c}\text { Stand. } \\
\text { pred. } \\
\text { val. }\end{array}$ & $\begin{array}{l}\text { Stand. } \\
\text { residual }\end{array}$ & $\begin{array}{c}\text { Std. } \\
\text { err. } \\
\text { pred. } \\
\text { val. }\end{array}$ & $\begin{array}{l}\text { Mahalan. } \\
\text { distance }\end{array}$ & $\begin{array}{l}\text { Deleted } \\
\text { residual }\end{array}$ & $\begin{array}{c}\text { Cook's } \\
\text { distance }\end{array}$ \\
\hline 1992 & 11.644 & 13.765 & 16,680 & $-5,036$ & $-1,042$ & $-1,125$ & 1,365 & 1,0868 & $-5,55$ & 0,071 \\
\hline 1993 & 0.601 & 4.889 & 6,014 & $-5,413$ & $-3,045$ & $-1,209$ & 3,053 & 9,2701 & $-10,12$ & 1,186 \\
\hline 1994 & 17.600 & 20.776 & 25,105 & $-7,505$ & 0,539 & $-1,676$ & 1,066 & 0,2905 & $-7,96$ & 0,089 \\
\hline 1995 & 17.111 & 10.417 & 12,657 & 4,454 & $-1,798$ & 0,995 & 1,954 & 3,2318 & 5,50 & 0,144 \\
\hline 1996 & 20.627 & 15.514 & 18,782 & 1,845 & $-0,648$ & 0,412 & 1,120 & 0,4199 & 1,97 & 0,006 \\
\hline 1997 & 28.756 & 15.049 & 18,223 & 10,533 & $-0,753$ & 2,352 & 1,178 & 0,5668 & 11,32 & 0,221 \\
\hline 1998 & 25.236 & 17.029 & 20,603 & 4,633 & $-0,306$ & 1,035 & 0,978 & 0,0938 & 4,87 & 0,028 \\
\hline 1999 & 24.271 & 15.383 & 18,625 & 5,646 & $-0,678$ & 1,261 & 1,136 & 0,4590 & 6,03 & 0,058 \\
\hline 2000 & 20.151 & 17.945 & 21,703 & $-1,552$ & $-0,100$ & $-0,347$ & 0,939 & 0,0099 & $-1,62$ & 0,003 \\
\hline 2001 & 22.112 & 19.209 & 23,222 & $-1,110$ & 0,186 & $-0,248$ & 0,950 & 0,0344 & $-1,16$ & 0,001 \\
\hline 2002 & 25.853 & 18.812 & 22,745 & 3,108 & 0,096 & 0,694 & 0,938 & 0,0092 & 3,25 & 0,012 \\
\hline 2003 & 27.986 & 22.092 & 26,687 & 1,299 & 0,836 & 0,290 & 1,228 & 0,6986 & 1,41 & 0,004 \\
\hline 2004 & 27.534 & 23.488 & 28,364 & $-0,830$ & 1,151 & $-0,185$ & 1,442 & 1,3242 & $-0,93$ & 0,002 \\
\hline 2005 & 27.938 & 22.756 & 27,485 & 0,453 & 0,986 & 0,101 & 1,326 & 0,9715 & 0,50 & 0,000 \\
\hline 2006 & 29.808 & 23.302 & 28,141 & 1,667 & 1,109 & 0,372 & 1,412 & 1,2294 & 1,85 & 0,008 \\
\hline 2007 & 29.703 & 22.559 & 27,248 & 2,455 & 0,941 & 0,548 & 1,296 & 0,8858 & 2,68 & 0,015 \\
\hline 2008 & 31.434 & 22.614 & 27,314 & 4,120 & 0,954 & 0,920 & 1,304 & 0,9093 & 4,50 & 0,043 \\
\hline 2009 & 25.039 & 19.929 & 24,087 & 0,952 & 0,348 & 0,212 & 0,991 & 0,1211 & 1,00 & 0,001 \\
\hline 2010 & 21.350 & 20.234 & 24,454 & $-3,104$ & 0,417 & $-0,693$ & 1,015 & 0,1737 & $-3,27$ & 0,014 \\
\hline 2011 & 20.628 & 19.822 & 23,959 & $-3,331$ & 0,324 & $-0,744$ & 0,984 & 0,1048 & $-3,50$ & 0,015 \\
\hline 2012 & 19.269 & 19.130 & 23,127 & $-3,858$ & 0,168 & $-0,862$ & 0,947 & 0,0281 & $-4,04$ & 0,018 \\
\hline 2013 & 18.858 & 19.641 & 23,741 & $-4,883$ & 0,283 & $-1,090$ & 0,972 & 0,0801 & $-5,12$ & 0,031 \\
\hline 2014 & 17.871 & 18.536 & 22,413 & $-4,542$ & 0,034 & $-1,014$ & 0,934 & 0,0011 & $-4,75$ & 0,024 \\
\hline \multicolumn{3}{|c|}{ Minimum } & 6,014 & $-7,505$ & $-3,045$ & $-1,676$ & 0,934 & 0,0011 & $-10,12$ & 0,000 \\
\hline \multicolumn{3}{|c|}{ Maximum } & 28,364 & 10,533 & 1,151 & 2,352 & 3,053 & 9,2701 & 11,32 & 1,186 \\
\hline \multicolumn{3}{|c|}{ Mean } & 22,234 & 0,000 & 0,000 & 0,000 & 1,240 & 0,9565 & $-0,14$ & 0,087 \\
\hline \multicolumn{3}{|c|}{ Median } & 23,222 & 0,453 & 0,186 & 0,101 & 1,120 & 0,4199 & 0,50 & 0,015 \\
\hline
\end{tabular}

Source: IMF, WEO Database April 2015, Own Calculation 
If we get a significant result, we can reject null hypothesis that there are no significant differences between the data and confirm the alternative hypothesis that there are statistically significant differences between the data. The total of 23 cases were included in the research for the period of time from the 1992-2014, regardless of the Left or Right - wing Government being in governance.

Table 2. T-test for Dependent Samples -Investment (marked differences are significant at $\mathrm{p}<$ $0.05000)$

\begin{tabular}{ccccccccc}
\hline & Mean & Std.Dv. & $\mathrm{N}$ & Diff. & Std.Dv. - Diff. & $\mathrm{t}$ & $\mathrm{df}$ & $\mathrm{p}$ \\
\hline Saving & 18.38657 & 4.433161 & & & & & & \\
Investment & 22.23391 & 6.893807 & 23 & -3.84735 & 4.465938 & -4.13155 & 22 & 0.000438 \\
\hline
\end{tabular}

Source: IMF, WEO Database April 2015, Own Calculation

The dependent t-test (table no. 2) proved great discrepancy in $t_{\text {calc }}$ in relation to $t_{\text {crit }}$, therefore our null hypothesis was discarded in terms of there not existing a difference between the two groups observed, which would imply investment rates were differing significantly from the saving in Croatia. At the same time, this would say that forcing of investment far beyond its own means on the part of the Government of Croatia, had a great impact in creating a macroeconomic misbalance of national economy. The aforementioned is presented in the graph no.3

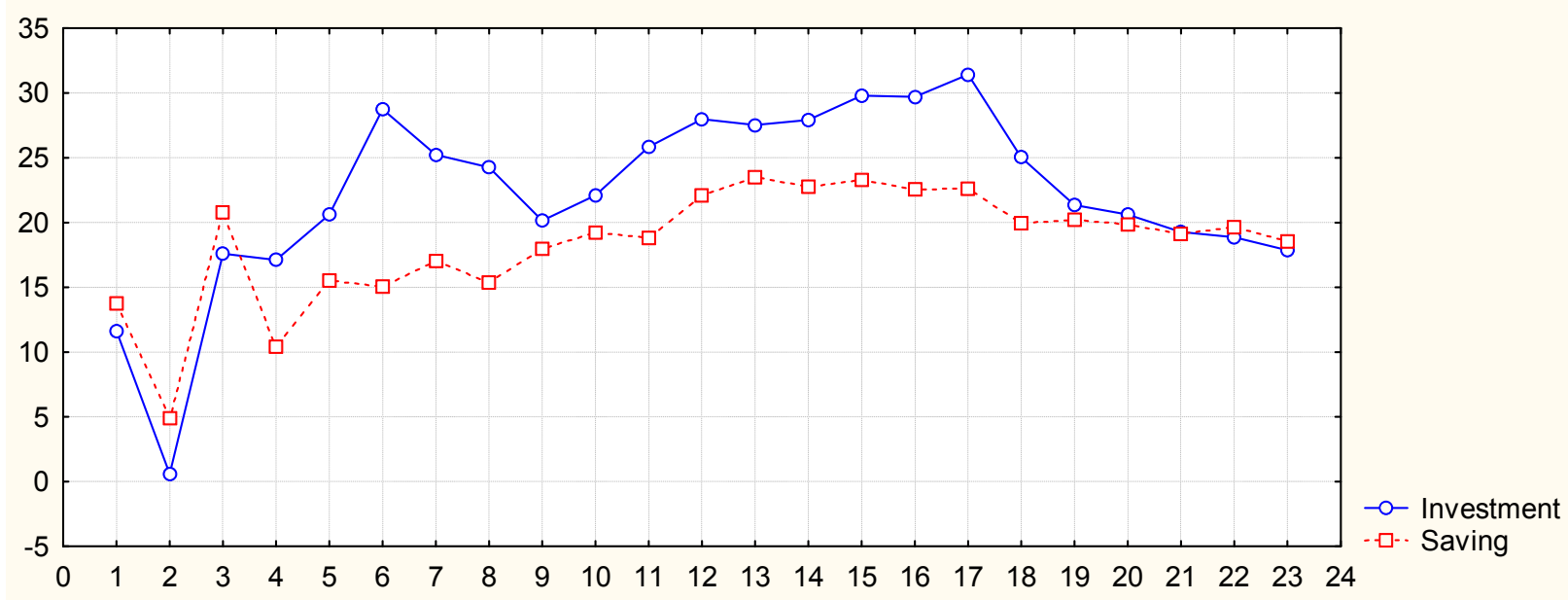

Graph 3. Saving and Investment Rate in Croatia, 1992-2014

Source: IMF, WEO Database April 2015, Own Calculation

All the data analyzed so far shows a significant saving - investment gap in Croatia, which is more than clear from the above graph. Generally speaking in all the periods there have been noted greater investment than saving rates, thus leading to the macroeconomic misbalance. This culminated particularly in the 1997 right after the War was over, when all the forces 
were put into winning back the lost investment cycle, reaching an investment rate of $28.76 \%$, which was double than the saving rate at that time reaching solely $15 \%$. Right after the War was over, investment rate in Croatia was higher in continuity than the saving rate (at times significantly), all this till 2010 when came the so called "sobering" period, resulted in implementing economic policy that would not lead to investing beyond ones' means without leaving economic consequences. With this regard we can consider the position Croatia has in EU as a small country that cannot seriously affect the microeconomic misbalance of the EU as a whole, but can nevertheless implement certain measures that will decrease rather than increase the existing microeconomic misbalance.

\subsection{Croatia and Its Governments Ideological Profile}

If we analyse the Governments in Croatia since its Independence, depending if they were Left or Right - wing ones, some interesting data will emerge in terms of the saving - investment gap forming. Right wing Governments had more political success and participated more in governance than the Left - wing ones. Therefore we will analyse the data obtained from of 16 cases of Right and 7 of the Left wing Governments. It is interesting to notice that Right wing Governments had an average investment rate of $23.91 \%$, higher than $21.73 \%$ average rate of the Left -wing Governments. If we exclude a delicate war period in the 1992, with the investment rate of solely $0.6 \%$, post war period marked greater investment rate of Right wing Governments reaching from $20.63 \%$ to $31.43 \%$, than the Left ones with $17.87 \%$ to $27.99 \%$.

On the other hand, the average saving rate for the Right - wing Governments was $17.97 \%$, which is lower than the average rate of 19.34 of the Left - wing Government. This brings us to a conclusion that the saving - investment gap was larger during the Right wing Governments in governance than the Left ones. From this we can see that for the Right wing Governments in that period a 4.43 additional points should be added to each saving rate to reach an investment rate coefficient, which would be a great challenge for those in charge of the economic policy. Investigating into the saving - investment correlation in times of Right wing Governments' governance, there was no evident balance between two groups, as presented in the graph no.4. In some cases it was clear that investment rates were double in value (the aforementioned case from 1997) than the investment rates. It is evident that the investment rate was higher in the whole period (except during the times of the War), than the saving rate, and therefore the difference between the two had to be covered using other means. 


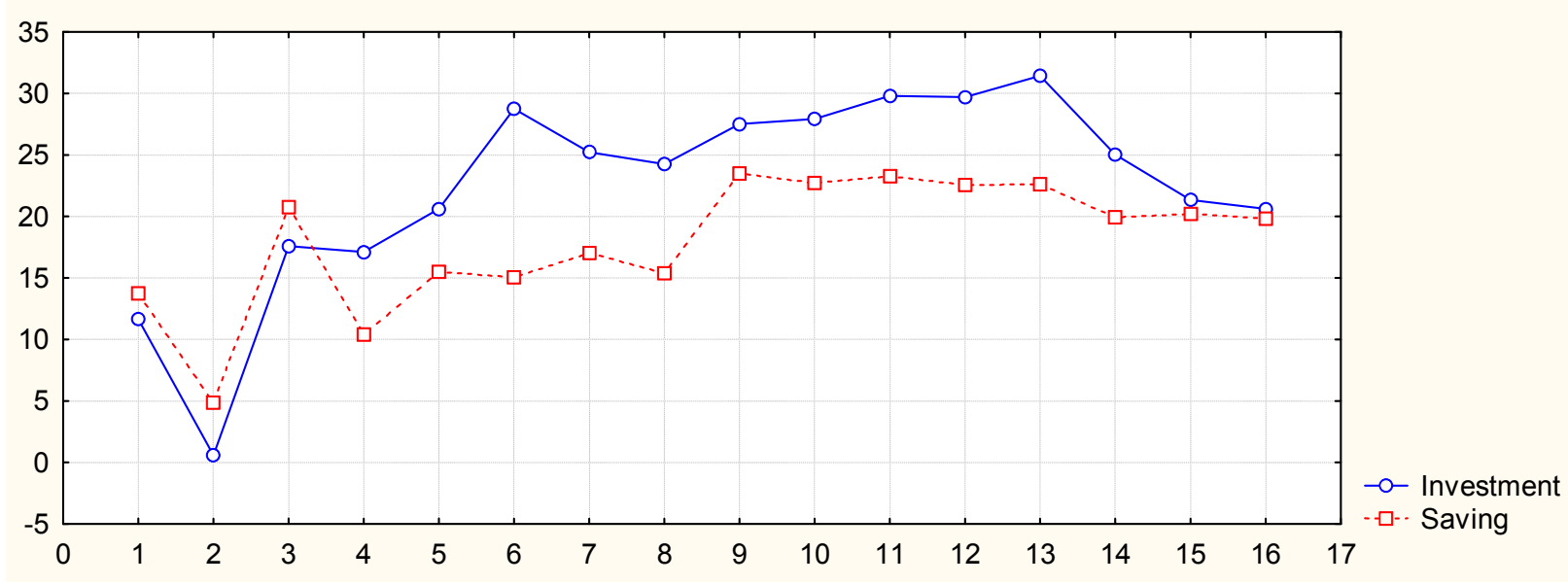

Graph 4. Investment and Saving in Right wing Governments in Croatia 1992-2014

Source: IMF, WEO Database April 2015, Own Calculation

However, with the further statistic analysis the high impact of the saving rates on the investment rates in Right - wing Governments was proved (table no.3). If the Right - wing Governments increase their saving rates, following their ideologies without opportunistically trying to reach the "middle voters", they will be able to effectively impact the saving investment gap without creating larger negative effects on microeconomic stability of the country. On the other hand, if they start turning to the "middle voters", abandoning their ideology, that will diminish their effectiveness in decreasing the saving-investment gap, and saving rate influence on the investment would be meagre. This conclusion can come in handy in times before elections, when political parties, regardless of being Left or Right wing, promise more to the ,middle, indecisive voters“ with the sole purpose of winning more votes that will ensure them a victory in elections.

Table 3. Saving and Investment Right - wing Government in Croatia 1992.-2014.

\begin{tabular}{|c|c|c|c|c|}
\hline $\begin{array}{l}\text { Dependent: Investment } \\
\text { No. of cases: } 16\end{array}$ & $\begin{array}{l}\mathrm{R}=0.80356592 \\
\mathrm{R} 2=0.64571819 \\
\text { adjusted } \mathrm{R} 2=0.62041234\end{array}$ & $\begin{array}{l}\mathrm{F}= \\
\mathrm{df}= \\
\mathrm{p}=\end{array}$ & $\begin{array}{l}1656 \\
4 \\
0177\end{array}$ & \\
\hline & \multicolumn{4}{|c|}{ Standard error of estimate: 4.915998642} \\
\hline 0.487380539 & Std.Error: 4.519150 & $\begin{array}{r}t(14)=0.10785 \\
\text { Var2 beta }=0.804\end{array}$ & $\mathrm{p}=$ & 0.9156 \\
\hline
\end{tabular}

Source: IMF, WEO Database April 2015, Own Calculation

From the research conducted it is evident that the saving-investment ratio in Left - wing Governments of Croatia was not a balanced one, but it shows lesser rates of misbalance than previously seen in Right - wing Governments. As seen in the graph no. 5. The greater discrepancy of investment rate in regard to the saving rate was in the 2002, with the 
investment rate of $25.85 \%$ and the saving rate of only $18.81 \%$. It is obvious that each investment rate should be increased by 4.51 points, thus presenting a big challenge to the bearers of the economic policy in governance. The same goes for the Right - wing Governments. However, for the period from 2012-2014 there is a change in the ratio between two groups, with the saving rate being higher than the investment rate, but still lower than an average EU rate.

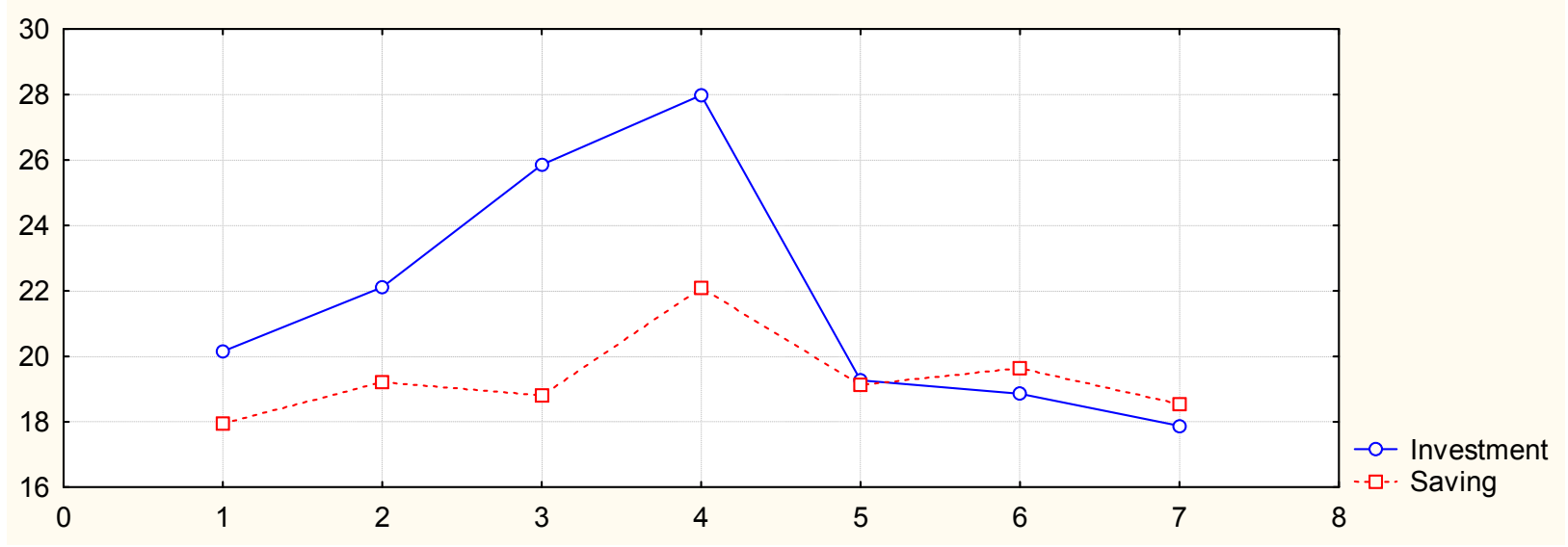

Graph 5. Saving - Investment in Croatia, Left - wing Government 1992-2014

Source: IMF, WEO Database April 2015, Own Calculation

With the further data analysis we noticed an influence of the saving rate on the investment rate to some extent, but still weaker than was the case with the Right - wing Governments (table no.4 ). Conducting the economic (investment) policy of Left-wing Governments can be effective only with a noticeable increase in saving rates. This phenomenon is still weaker than the one in the Right- wing Governments.

Table 4. Saving - Investment in Croatia, Left - Wing Government 1992-2014

\begin{tabular}{|c|c|c|c|}
\hline Dependent: Investment & $\mathrm{R}=0.65331923$ & \multicolumn{2}{|c|}{$\mathrm{F}=3.723355$} \\
\hline \multirow{3}{*}{ No. of cases: 7} & $\mathrm{R} 2=0.42682601$ & \multirow{2}{*}{\multicolumn{2}{|c|}{$\begin{array}{l}\mathrm{df}=1.5 \\
\mathrm{p}=0.111548\end{array}$}} \\
\hline & adjusted $\mathrm{R} 2=0.31219121$ & & \\
\hline & \multicolumn{3}{|c|}{ Standard error of estimate: 3.175645037} \\
\hline Intercept: -14.67341449 & $\begin{array}{l}\text { Std.Error: } 18.90319 \\
\text { Var2 beta }=0.653\end{array}$ & $t(5)=-0.7762$ & $\mathrm{p}=0.4727$ \\
\hline
\end{tabular}

Source: IMF, WEO Database April 2015, Own Calculation

With goals of increasing the saving rates, and following their ideology, Left - wing Governments with all these efforts will not be as effective as the Right - wing ones. They will be less focused on bringing in balance the saving - investment gap. If the Left - wing Governments try to reach out the „middle voters" that could enhance their effectiveness in 
decreasing the saving- investment gap. This findings can come in handy in times before elections, when they turn to "middle, indecisive voters", with the sole purpose of winning more votes, without in any way affecting in a negative fashion the macroeconomic stability of the country.

\section{Conclusion}

Croatia in years to come after reaching its Independence and adopting economic markets` conditions did not have a balanced saving-investment correlation. The pursuit of economic growth going for the investments far beyond its means, led Croatia's economy into forming of the saving - investment gap, alongside macroeconomic misbalance. It is important to increase the saving rates to reach levels of the investment rate. Even though implementing of economic, (investment) policy of Right - wing Governments had a great impact on saving in terms of influencing the investment rate, it led to creating the saving - investment gap, of larger proportions than it was in times of Left - wing Governments.

If Right - wing Governments of Croatia continue increasing savings at hand, adhering with their ideology, and turning less to the ,middle voters“, they will reach a very effective position that could enable saving - investment correlation, and creating of the macroeconomic stability. In case they start turning to the „middle“ voters, and abandoning along the way their ideology, this would result in slightly decreasing the saving - investment gap, and weakening of the influence of saving on the investment in general. On the other hand, if the Left- wing Governments in implementing the measures of economic policy that would increase the saving rate, follow their ideology, this will ensure them great position from which to set the saving - investment into balance. If however, they start turning to the „middle“ voters that would improve even further the implementation of measures with which one can effectively influence the saving - investment balance in Croatia.

\section{References}

Adom, A.D., \& Elbahnasawy N. G. (2014). Saving-Investment Gap and Economic Growth in Developing Countries: Simulated Evidence from Selected Countries in Africa. British Journal of Economics, Management \& Trade, 4(10), 1585-1598. http://dx.doi.org/10.9734/BJEMT/2014/10588

Afzal, M. (2007). Savings and Investment in Developing Countries: Granger Causality test. Philippine Review of Economics, 44(2), 34-44

Aizenman, J., Pinto, B., \& Radziwill A. (2007). Sources for financing domestic capital-is foreign saving a viable option for developing countries? Journal of International Money and Finance, 26(5), 682-702. http://dx.doi.org/10.2139/ssrn.561045

Bahmani-Oskooee, M., Hegerty, S.W., \& Wilmeth H. (2012). The Saving-Investment Gap And Income Inequality:Evidence From 16 Countries. Journal of Developing Areas, 
Tennessee State University, College of Business, 46(2), 145-158. http://dx.doi.org/10.1353/jda.2012.0032

Blanchard, O., \& Giavazzi F. (2002). Current Account Deficits in the Euro Area: The End of the Feldstein Horioka Puzzle?, Brookings Papers on Economic Activity, Economic Studies Program, The Brookings Institution, 33(2), 147-210. http://dx.doi.org/10.1353/eca.2003.0001

Cass, D. (1965). Optimum Growth in an Aggregative Model of Capital Accumulation. Review of Economic studies, 32(3), 233-240. http://dx.doi.org/10.2307/2295827

Cooray, A., \& Sinha D. (2007). The Feldstein-Horioka model re-visited for African countries. Applied Economics, 39(12), 1501-1510. http://dx.doi.org/10.1080/00036840600675679

De Wet, A., \& Van Eyden. (2005). Capital Mobility in Sub Sub-Saharan Africa: A panel Data Approach. South African Journal of Economics, 73(1), 22-35, http://dx.doi.org/ 10.1111/j.1813-6982.2005.00002.x

Esso, L.J., \& Keho. (2010). The Savings - Investment Relationship: Cointegration and causality Evidence from Uemoa Countries. International Journal of Economics and Finance, 2(1), 174-181. http://dx.doi.org/10.5539/ijef.v2n1p174

Feldstein, M., \& Horioka C. (1980). Domestic Savings and International Capital Flows. The Economic Journal, 90(358), 314-329. http://dx.doi.org/ 10.3386/w0310

Feldstein, M. (1983). Domestic saving and international capital movements in the long run and the short run. European Economic Review, 21(1-2), 129-151, http://dx.doi.org//10.1016/s0014-2921(83)80012-9

Frankel, J.A. (1992). Measuring International Capital Mobility: A Review. American Economic Review, American Economic Association, 82(2), 197-202.

Hibbs, D. A. (1977). Political Parties and Macroeconomic Policy. The American Political Science Review, 71(4), 1467-1487. http://dx.doi.org/10.2307/1961490

Keynes, J. M. (1936). The General Theory of Employment, Interest and Money. The Collected Writings of John Maynard Keynes, VII, Royal Economic Society 1978, http://dx.doi.org/10.1017/UPO9781139524278.001

Koopmans, T. C. (1965). On The Concept of Optimal Economic Growth, in The Econometric Approach to Development Planning, Amsterdam: North-Holland, Pontif. Acad. Sc. Scripta Varia 28, 225-287., reprinted in Koopmans (1979), 563-594.

Mishra, P.K., Das J.R., \& Mishra, S.K. (2010). The Dynamics of Saving and Investment Relationship in India, European Journal of Economics, Finance and Administrative Sciences, 18, 163-172.

Nordhaus, W. D. (1975). The Political Business Cycle. Review of Economic Studies, 42(2), 169-190. http://dx.doi.org/10.2307/2296528 


\section{Macrothink}

Obstfeld, M. (1986). Capital mobility in the world economy: Theory and measurement. Carnegie-Rochester Conference Series on Public Policy. Amsterdam, North-Holland, 24, 55- 103, http://dx.doi.org/10.1016/0167-2231(86)90005-9

Obstfeld, M., \& Rogoff K. (1997). Foundations of International Macroeconomics. Southern Economic Journal, 64(1), 337-339. http://dx.doi.org/ 10.2307/1061063

Onafowara, O. A., Owoye, O., \& Huart, F. (2011). The Temporal Relationship between Saving and Investment: Evidence from Advanced EU Countries. International Journal of business and Social Science, 2(2), 1-12.

Prasad, E. S., Rajan R. G., \& Subramanian A. (2007). Foreign Capital and Economic Growth. Brookings Papers on Economic Activity, 38(1), 153-230, http://dx.doi.org/10.1353/eca.2007.0016

Ramsey, F. (1928). A Mathematical Theory of Saving. Economic Journal, 38(152), 543-559, http://dx.doi.org/10.2307/2224098

Sanjib, B., \& Joice J. (2011). Are Saving and Investment Cointegrated? A Cross Country Analysis, Reserve Bank of India, Occasional Papers Vol. 32(1), 42-55.

Schneider, B. (1999). Saving-Investment Correlations and Capital Mobility in Developing Countries with Special Reference to India. Indian Council for Research on International Economic Relations, Working Paper No. 48.

Solow, R. M. (1956). A Contribution to the Theory of Economic Growth. The Quarterly Journal of Economics, 70(1), 65-94. http://dx.doi.org/10.2307/1884513

\section{Copyright Disclaimer}

Copyright for this article is retained by the author(s), with first publication rights granted to the journal.

This is an open-access article distributed under the terms and conditions of the Creative Commons Attribution license (http://creativecommons.org/licenses/by/3.0/). 